\title{
INTERACTIVE LEARNING METHOD BASED ON INFORMATION COMMUNICATION TECHNOLOGY
}

\author{
Lucy Pujasari Supratman \\ School of Communication and Business, Communication Department, Telkom University \\ Jl. Telekomunikasi, Terusan Buah Batu, Bandung, Jawa Barat, 40257, Indonesia \\ No. Telp./HP: +62(22)7564108/+6281221524351 \\ E-mail: lucysupratman@telkomuniversity.ac.id
}

\section{Naskah diterima tanggal 2 Oktober 2017, direvisi tanggal 5 April 2018, disetujui tanggal 24 September 2018 \\ METODE PEMBELAJARAN INTERAKTIF BERBASIS TEKNOLOGI INFORMASI DAN KOMUNIKASI}

\begin{abstract}
There are many models of lecturing method in higher education level. Telkom University as a university that based on Information and Communication Technology (ICT) applies its teaching and learning method through the use of internet facility. Based on research, we found that the interactive learning method based on ICT was applied well. The numbers of classes that had been involved were three classes, the classes observed in applying the interactive learning method based on ICT (high-speed wifi, digital slide projector, audio video interactive facility using YouTube and Blogspot). This interactive learning method based on ICT collaborate the lecturer-student proximity at class. The research used a descriptive case study to elaborate the classes for the whole semester. The result found that this method proved successful in sharpening student's critical thinking. The student's perspective to analyze social phenomenon in the society have broadened fast. It helped the student to build courage in delivering critical argument orally and written.
\end{abstract}

Keywords: information and communication technology (ICT), learning method, interactivity.

\begin{abstract}
Abstrak. Terdapat banyak model pengajaran yang dapat diaplikasikan di tingkat perguruan tinggi. Universitas Telkom sebagai kampus berbasis Teknologi Informasi dan Komunikasi (TIK) menerapkan model pengajaran dan pembelajarannya dengan menggunakan basis fasilitas teknologi internet. Berdasar penelitian ini, penulis menemukan bahwa metode pembelajaran interaktif berbasis TIK sangat efektif dipergunakan. Jumlah sampel yang dilibatkan yaitu tiga kelas dan telah dilakukan observasi pada ketiga kelas tersebut dengan menerapkan metode pengajaran interaktif berbasis TIK (akses internet berkecepatan-tinggi, layar proyektor digital, fasilitas interaktif audio video menggunakan YouTube dan penggunaan Blogspot). Metode pembelajaran interaktif berbasis TIK ini melakukan kolaborasi antara dosen dan mahasiswa di kelas. Penelitian menggunakan studi kasus deskriptif untuk mengelaborasi seluruh kelas selama satu semester penuh. Hasil penelitian menunjukkan bahwa metode tersebut terbukti berhasil dalam membentuk pola berpikir kritis para mahasiswa. Sudut pandang para mahasiswa dalam menganalisis fenomena sosial di masyarakat berkembang dengan cepat. Metode tersebut sangat membantu para mahasiswa dalam menyampaikan gagasan kritis baik secara lisan maupun tertulis.
\end{abstract}

Kata kunci: teknologi informasi dan komunikasi (TIK), metode pembelajaran, interaktif. 


\section{INTRODUCTION}

A creative lecturing method in higher education level is sometimes seen to be a complimentary way by the lecturer nowadays. In fact, it can boost the motivation of the students to internalize the subject. As a research from Sajjad (2010), various method of lecturing explained in many ways. In Sajjad previous research, most of the students rated lecture method as the best teaching method. The lecturer provides all knowledge related to the topic. It is time-saving because the students only listen to the lecture and take notes. The group discussion was rated as the second best method of teaching. The students do not have to rely on note learning, and it develops creativity among students.

While Degeng (2004) has a contrary to Sajjad thought and further sees that the quality of learning will increase when it involves the learners to interact in the classroom. Degeng said that the quality of learning could be seen from two aspects, aspects of the process and terms of learning outcomes. Improving the quality of learning regarding the process is an effort to improve the quality of the learning process that leads to the occurrence or emergence of learning initiatives by learners. This can only happen if the learning strategy is based on a suitable theoretical basis, which gives more opportunities for learners to experience growth of learning.

The research initiated by the Communication Management course. This course is one of the obligatory subjects that related to the daily phenomenon. Thus, the critical power of students needs to be sharpening among them in analyzing a challenging social phenomenon in society. This Communication Management subject is a mandatory course for every student in majoring Communication Studies. The students need to understand the subject both theoretically and practically. This research recommended in applying the interactive learning method based on ICT in the Communication Management classes. The numbers of classes that have been involved in this research were three classes. The classes were observed before applying the interactive learning method based on ICT. The ICT learning method is a lecturing method by using internet technology to increase lecturerstudents proximity at class. The lecturer uses ICT facilities as a teaching tool, allow all students to use their freedom of speech, surf the internet with wi-fi, smartphone or tablet to collect authentic data with the latest news updates associated with the communication management, and published the learning output in official online sites.

The goal of using ICT method is to make the easier interaction between lecturers and millennial students. These students are used to call with Generation $Z$. These students are used to call with Generation Z. As Seemiller \& Grace (2016) stated that generation $\mathrm{Z}$ students are realistic problem solvers who like the problem solving subject. They do not like to be protected from problems (sugar-coated). They would rather face an issue head-on and be part of the solution. This is what the millennial lecturer need to understand that the millennial student's characteristics are different compared to students before them. According to Prensky (in Cornu, 2011), the millennials are the generation of technological acceleration of the internet and their networks. Prensky also said that technology has become their integral part of their life and become the mother tongue for them.

The ICT usages in teaching and learning process are in line with Telkom University roadmap. Telkom University students are very familiar with using ICT learning method. It makes Telkom University as one of the most ICT based education modern private universities in Indonesia. So, the research problem in this study is "How does the interactive learning method based on ICT apply in Higher Education Level?" The general objective of this class action research is to improve student's critical reasoning ability. The class subject to be chosen is Communication Management. The students need to master this subject as an integral foundation of communication ontology to build effective communication. 


\section{CONCEPT}

The teaching and learning process at the higher university level in Indonesia is not really sharpened students critical thought. As research from Slameto (2014), the Indonesian education system does not teach how to think critically. On Slameto's research, the teacher played in the context of curriculum, learning, and evaluation. While it arouses the results from World Bank (2014) that the Indonesian teachers are the lowest in Asia as its role to be the agent of change, has the very low productivity, and many factors that influence them. It is associated with the development of critical thinking, the practice of teaching and learning by teachers in primary schools, encouraging the achievement of the necessary critical thinking skills. Teachers have to complete the target of extensive material. It makes them getting focused on the completion of the materials. The teachers are lack of understanding about the teaching methods which cannot improve critical thinking skills. The method to sharpen critical thinking to the students can be in various ways. Supratman (2015) has also researched delivering the material to the students through seating arrangement. She has done her research to the classroom with a circle style of seating arrangement. The students mentioned it very helpful to catch the material. Rather than doing the seating with classical style like rows seating arrangement style, circle style is more interesting for the students. Rows seating arrangement locate the teacher at the front, and the interaction is less among the students. This is the alternative solution to motivate student's communication interactivity.

\section{RESEARCH METHOD}

This interactive learning method based on ICT is a revolutionary teaching style nowadays. Telkom University embraced the use of information communication technology as a tool to facilitate students advanced learning at class. According to Gichuru \& Mbayi (2016) learning model is an extension of the previous model's response system technology. Thus, these models incorporate components that could be expanded in certain subjects. The ability of this model allows lecturers to deliver material effectively with the assistance of technology. Thus, the research method we have used in a qualitative study with a descriptive case study approach. The data collection was gathered from students FGD (Focus Group Discussion), class action observation, a literature review on students assignment and scoring progress for three months (one semester). This learning method applied in three classes. The method reflected democratic and freedom of speech learning environment that allows learners to control over the fulfillment of emotional needs, expand critical analysis which involved emotionally, and mentally. One crucial element related to this strategy is how to arrange the class environment. It should be a fun activity, motivating and exciting for students. This element is often overlooked in today's learning management.

\section{RESULT AND DISCUSSION}

This research was conducted in three classes, Communication Management class of KM 38-MC1, Communication Management class of KM 38-MC3 and Communication Management class of KM 38-BR2. The number of students in the MC1 class is 40 students, the number of students in the MC3 class is 40 , and the number of students in the BR2 class is 40 students. The competencies that the writer observe in the classes are the enthusiasm to follow the course of Communication Management. The research is done through interactive learning methods based on ICT by me who act as the lecturer and observer at once. The writer prepared through several competencies. The competencies process are gaining students enthusiasm in cognitive and connative aspects. The first competence in observing the class is by preparing the teaching materials in the form of materials which derived from the lesson plan for one semester. The interactive learning method based on the ICT is one of the teaching methods that the 
writer choose to apply to the 3rd-semester student's classes. The interactive learning method based on ICT is a method that combines the use of technology to assist students in using their critical power. Technology, in this case, is YouTube, Blogspot, social media, and Kompasiana to help the students in pouring their critical thinking and the learning process in the classroom. The writer began observing the classroom by making sure the learning support tools were functioning properly (laptop, wi-fi internet, projector, projector slide, cable, and digital loudspeaker). The writer intentionally arrived half an hour earlier than the start of class time to prepare the learning facilities with very mature support. After all the tools work properly, the writer begin to prepare the record as the first term report.

The second competency is evaluating student character. The characteristics of students in the three classes are different. Characteristics of students in the MC3 class are more fluid, happy, full of jokes and chatter spontaneously. Characteristics of students in the class MC1 are very orderly, quiet and submissive. Meanwhile, the characteristics of students in the class of BR2 are outspoken. According to research reports in the first cycle, the three classes are paying great attention to the material of communication management. This is because the writer start the material not by discussing the complicated theory or concept of communication management, but starting from a sample news coverage of news from Malaysia that reports a child who was ignored by his biological mother. The mother locked her child in a room without being fed and drunk for months. Then, the writer capture some scenes associated with the management of communication courses. The purpose of using online news through YouTube is the introduction of the interactive learning method based on ICT indirectly to all students in the classroom. After several scenes capture showed, the writer associate the scene with teaching materials of communication management in the first week.

Moving on to the second cycle, the writer have executed the interactive learning method based on ICT on three classes in a couple of weeks. The interactive learning method based on ICT is one of the teaching methods chosen to be applied in social classes. Interactive learning method based on ICT is a method that combines the use of internet technology to help students to use their critical resources as learning goals in the classroom. Internet technology, in this case, is a tool that helps the learning process. The use of Blogspot and Kompasiana, as well as final grades, helps the student to express their critical thinking. It can be an indicator of students' achievement to have an out of the box though. The data will be collected through observation sheets, field notes, as well as interview techniques from the students. This research was conducted in three classes of Communication Studies, Faculty of Communication and Business, Telkom University. Here are the names of the classes (Table 1).

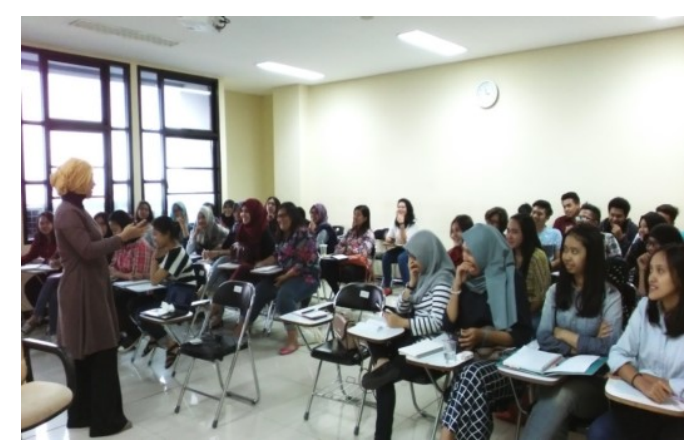

(a) 


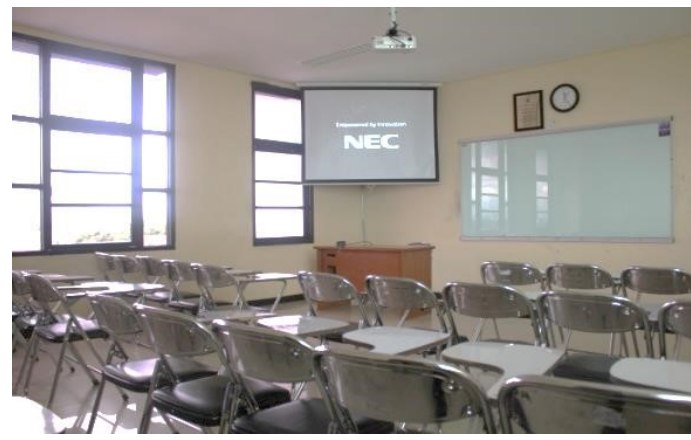

(b)

Source: Research Data (2018)

Figure 1. Supporting facilities of interactive learning method based on ICT method in the class.

Table 1

Three classes of Communication Studies, Faculty of Communication and Business, Telkom University

\begin{tabular}{ccc}
\hline Course & Class & Time \\
\hline Communication Management & KM 38-3 & $14.30-16.30$ \\
Communication Management & KM 38-2 & $10.30-12.30$ \\
Communication Management & KM 38-1 & $08.30-10.30$ \\
\hline So
\end{tabular}

Source: Research Result (2018)

Table 2

Number of Research Subject

\begin{tabular}{cc}
\hline Class & Student Numbers \\
\hline KM 38-3 & 40 students \\
KM 38-2 & 40 students \\
KM 38-1 & 40 students \\
\hline
\end{tabular}

Source: Research Result (2018)

The timeline of this research was started at the beginning of the first semester. The number of students in class is 40 students at KM 38-3, 40 students at KM 382, and 40 students at KM 38-1. The following table (Table 2) are the research subjects were used as data analysis in this research.

Based on the observations in the first meeting, the level of critical thinking skills students was not sharpened yet. The atmosphere of all classes was not alive. The learning environment in the classroom is very monotonous because it is dominated by an active lecturer who gives the speech a whole credit semester. The lecturer opened up the discussion; there were only a few students who dare to express their thoughts in class. Throughout the second term, the students who actively participated in the class were still dominated by the same people. On the next meeting, the classes started to pay great attention to the matter of communication management. This is because the lecturer began with a discussion of a true story about a boy (Muhammad Firdaus Dullah) who starved and cagedbrackets for months by his mother. The lecturer explained the true story of a boy by inserting communication theories. This YouTube video channel was selected because it related to a case to $b$ e discussed in communication management. The story was told by displaying the video news from Malaysia television tv1 station on YouTube Channel 'beritanasionalrtm rasmi'. The duration of the video is eight minutes. After watching it, the lecturer narrated again in theoretically way. It takes two credits to enliven the discussion about the boy. Below picture is the class atmosphere when the YouTube watching session in ongoing.

The purpose of using video through YouTube is the introduction to the students 
about the interactive learning method based on ICT. These cycles were continued to the next step of the interactive learning method based on ICT for six weeks. The result was astonishing. Students scored activeness in class and showed good progress. They are willing to play an active role in all discussions. Not only had a serious discussion about a topic from YouTube but also online news sites become the topic to be discussed. At the second term after the midtest, all students are assigned to make blogs. The result of the discussion at class should be published online. The representation lists of students blogs are in Table 3.

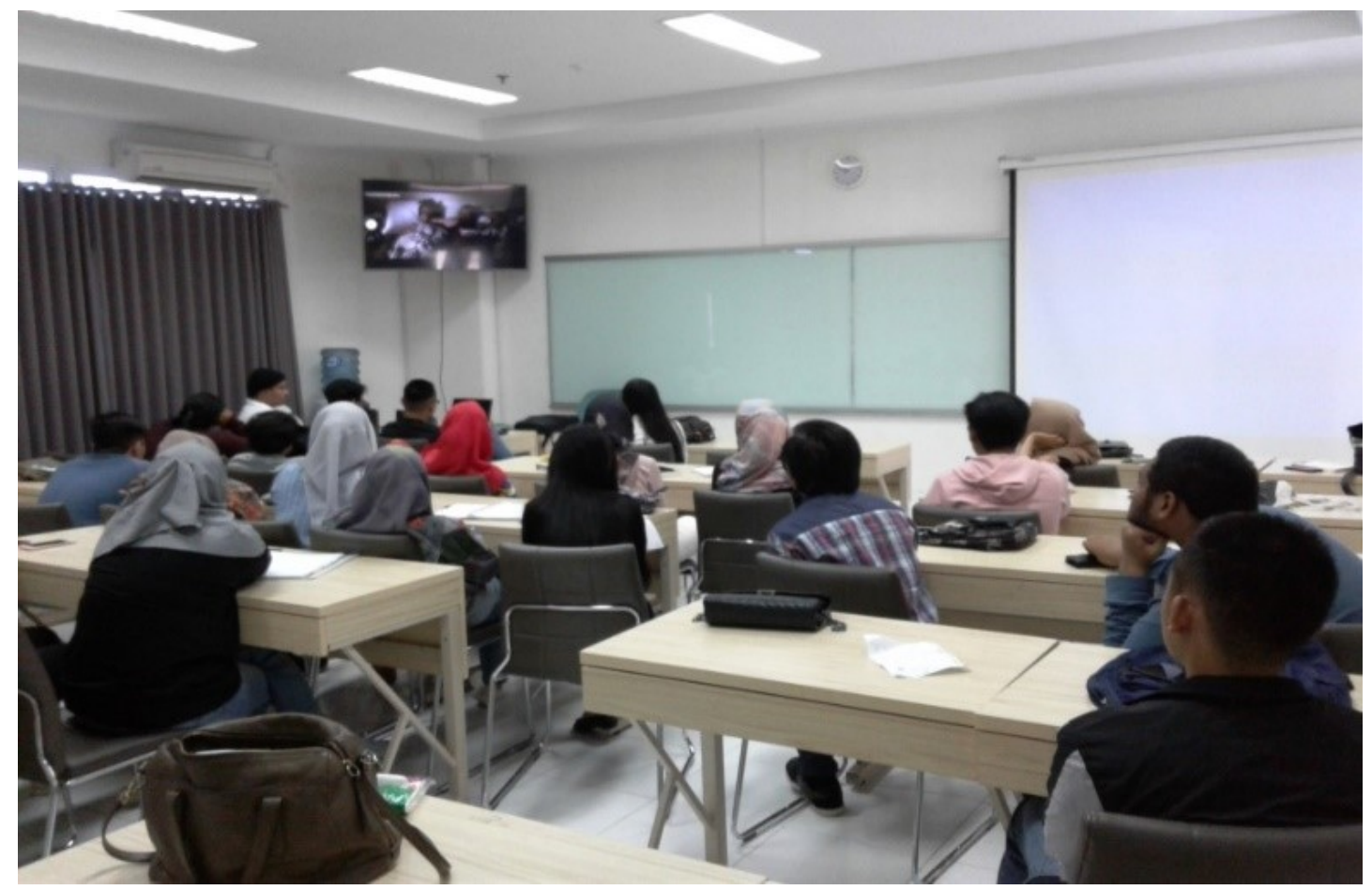

Source: Research Data (2018)

Figure 2. Youtube watching session and discussion in the class.

Table 3

Digital Blogs of Classes Assignment Blogspot Screenshot
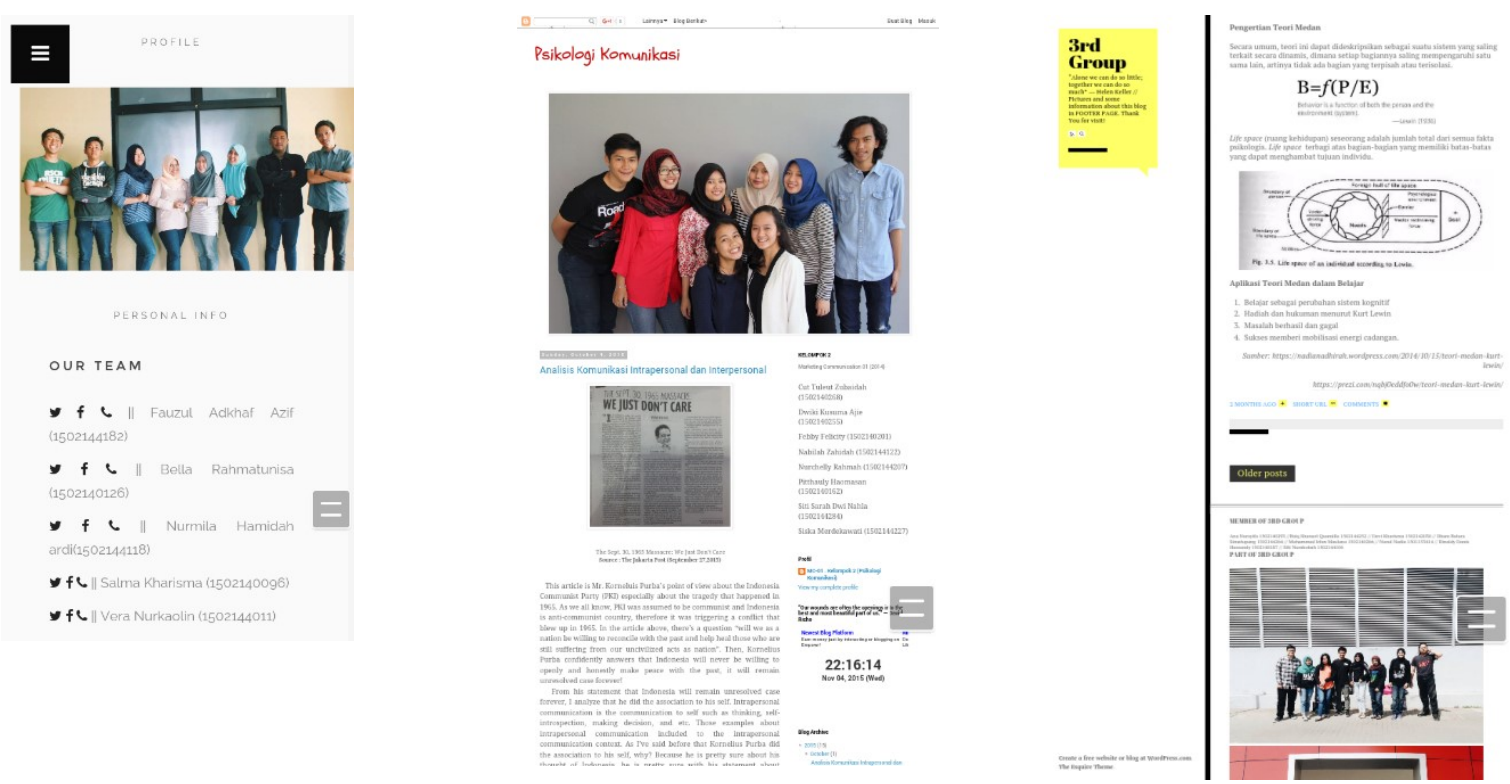
The content of the blog mostly had the critical content to an issue. Task essay blogs had four criteria for assessment. The content should be real-time $(10 \%)$, critical analysis $(30 \%)$, the insertion of the psychological theory of communication $(30 \%)$, and the solutions to these problems $(30 \%)$. The score is not in number but is a statement. The score statement is divided into five categories. The first category is 'excellent analysis' with the translation as follows: online news sources is validated properly, the content should be in the actual news, a comprehensive analysis by taking the case of online news and analyzed using psychological theories of communication, critical thinking in discussion analysis, involving conclusions or suggestions. The second category is 'wonderful analysis' with the translation as follow: the explanation only using the theory of communication and discussion of critical only. The third category is 'good analysis' with the translation as follow: delivering the analysis using the theory without wrapping it in critical analysis. The fourth category is 'shallow critical analysis' with the translation as follow: narrating the phenomenon but no explanation of the theory and discussion. The last category is 'zero analysis' with the translation of news online content only.

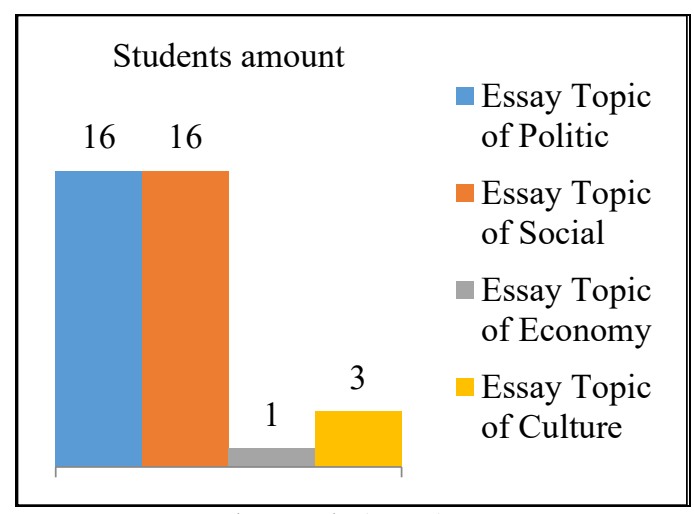

Source: Research Result (2018)

Figure 3. Chart of Critical Essay Blogspot Class KM 38

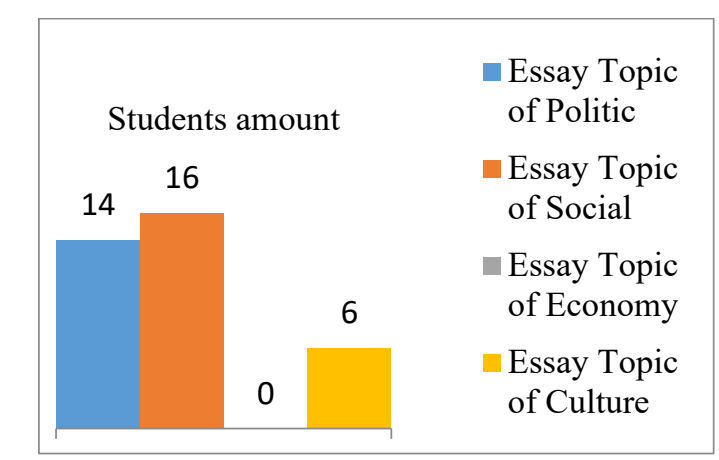

Source: Research Result (2018)

Figure 4. Chart of Critical Essay Blogspot Class KM 38-1 


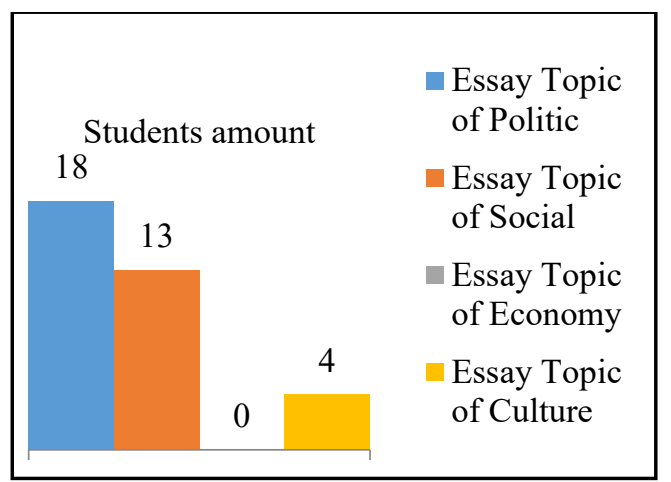

Source: Research Result (2018)

Figure 5. Chart of Critical Essay Blogspot Class KM 38-2

This interactive learning method based on ICT has proved successful in sharpening students' critical power. The evaluation of its success was shown on the answer sheet of mid-test and final test. Their answers used critical perspective in the test. The FGD at class really helps them to build the courage in delivering critical argument orally and written. Here are the achievements scores of the three classes after being executed by an interactive learning method based on ICT (Figure 6).

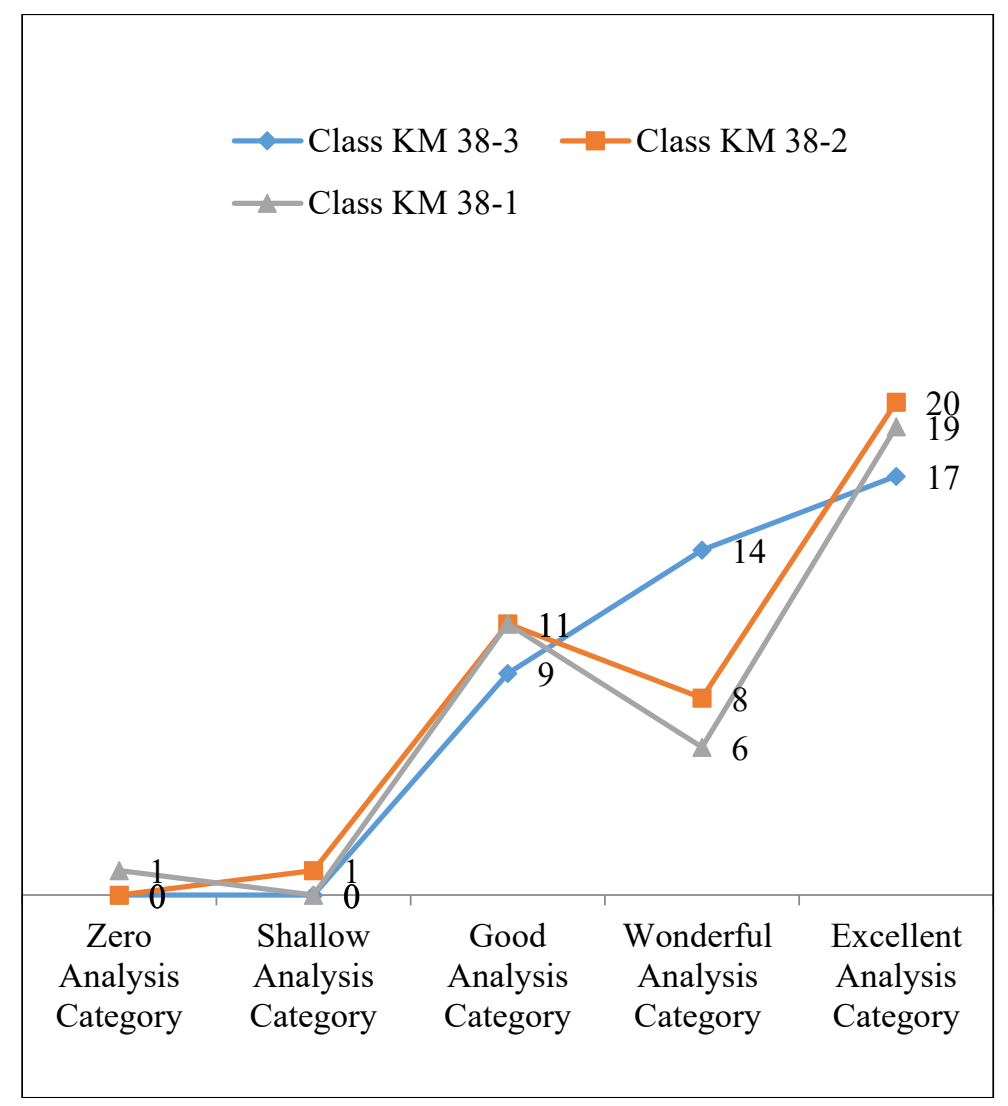

Source: Research Result (2018)

Figure 6. Students Progression in Critical Thinking 


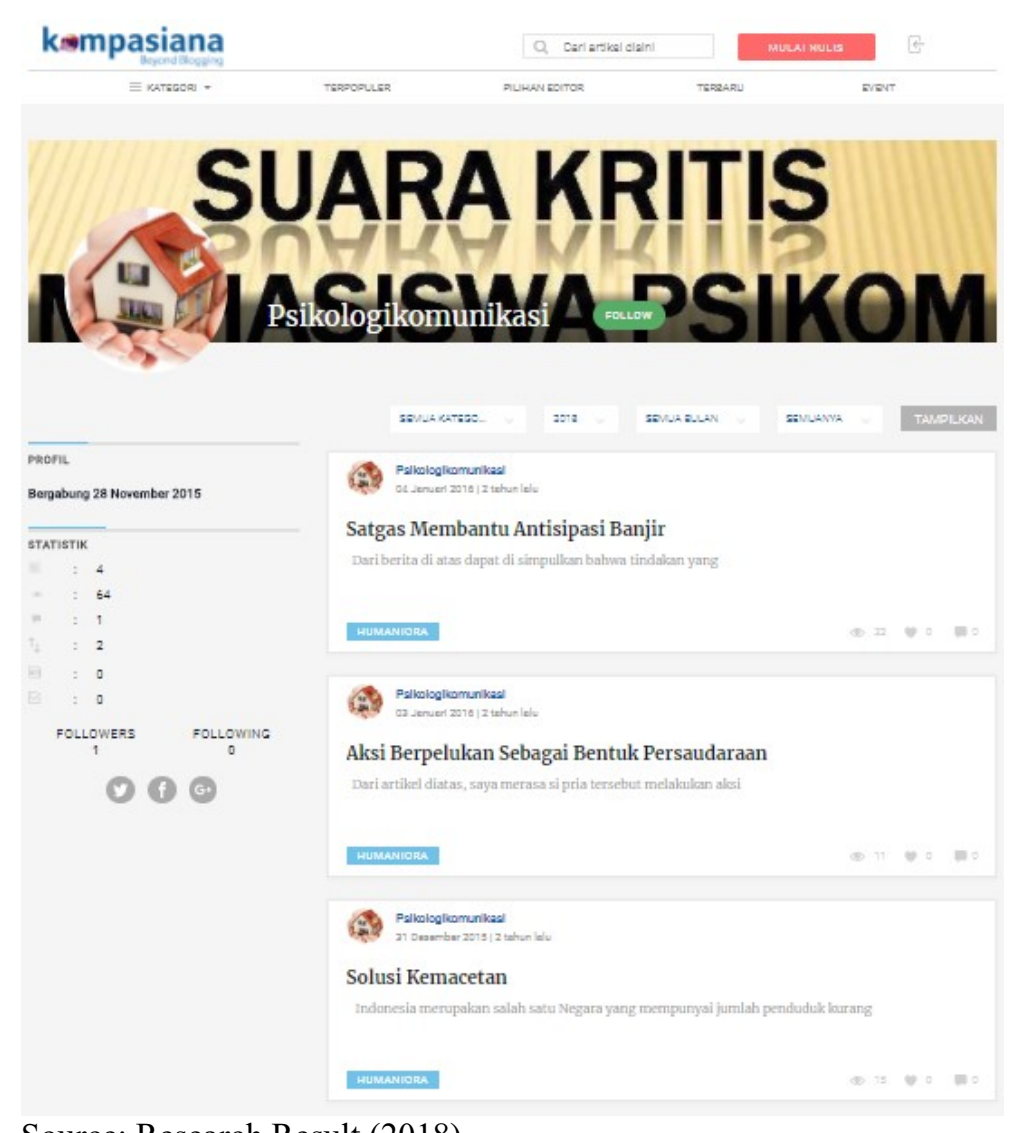

Source: Research Result (2018)

Figure 7. One of Students Essay in Kompasiana Acocunt.

As the observation go along for weeks, there are some students who remain passive students. They are quite ashamed to express their arguments. The active students are still the same students who participated in the discussion each week. Then, the writer reflect this feedback to modify the interactive learning method based on ICT with individual assignment. This individual assignment is called 'argumentative essay'. The students need to write their own arguments to criticize social phenomenon around them and post it to Kompasiana website. Kompasiana is chosen because it contains a bunch of writers who read, share and comment on the articles.

Kompasiana website is an interactive learning method based on ICT to be used in the process of critical discussion in the classroom. Of the three classes, the writer select one article from each class as a written representation for discussion. Here's the look of the Kompasiana website that the writer display based on three posts which belong to the students.
The display articles that I choose from the three classes are: (1) Task Force Helps Anticipate Flood, (2) Hugging Action as an Act of Brotherhood, (3) Traffic Jam Solutions. Here is one of the students' writing on Kompasiana website (Figure 7) entitled "Traffic Jam Solutions". It has been discussed with all students at class. The essay is analyzed to get pros and cons arguments from the participated students. The FGD function is to express student's critical thinking about the case that is closely related to communication management and measuring it into critical perspective. The task of the essay should be selected first in order to avoid the content of SARA (tribe, religious and races). The writer contemplate finding a solution for the majority of students to enliven class discussion with the criticality of each individual without being a follower. The writer was looking for reference sources for more lively learning communication. Iriantara (2014) describes the proximity of teachers and students in the communication of learning in the classroom. According to 
Iriantara, the closeness is important in the learning process because the proximity is the other side of the learning that makes the lecturer is not just a person whose job is to deliver learning materials. Lecturers teach their knowledge by using the personal side. Lecturers can encourage students interested in giving a full space for the student's time to think, analyze and to talk to the class. Lecturers should have personal skills approaching in students as well. Lee Swanson \& Sachse-Lee (2000) says that good interpersonal relationships, among others, are marked by proximity, showing teacherstudent communication not only in the classroom during the learning process. Interpersonal relationships can take place inside and outside the classroom. Lee Swanson's approach is emphasized on how the teacher acts as a harmonious relationship holder for students to have a great interest in learning. The writer eventually adopted Lee Swenson's approach as a self-reflective to open the space for students asking about everything related to communication management outside of the classroom. The modifications are still using the interactive learning method based on ICT, which is the personal approach pattern with the three classes of students using the LINE social media. Is open the communication space for students who want to ask more about the material and the phenomenon surrounding the communication management using LINE social media. This research chose LINE because the largest user of social media in the three classes is LINE, compared to WhatsApp or Snapchat. Even in the process of making blog assignments, the writer deliberately ask them to communicate through LINE so they are familiar with the interactive learning method based on ICT.

The type of student who already got the interactive learning method based on ICT divided into two types, there were the adaptive type and supportive type. The adaptive type was not too difficult to follow the pattern of teaching materials using internet technology to issue a critical argument in class. As for the supportive type students, they should be encouraged even persuaded repeatedly to voice their opinions, even for a single sentence. They were in shock by the accustomed of lecturer teaching pattern centered to interactive learning method based on ICT. It was because they were already accustomed to having lecture method by listening to lecturer speech. The application of the interactive learning method based on ICT in class was still being considered as a new thing. In the context of the communication field, this form of communication method was not yet to be explored, while having a critical communication point of view was the milestones key to digesting the theories.

The students found that the interactive learning method based on ICT was a new thing. It was conducted through focus group discussions in the classroom. In the beginning, they were reluctant to communicate in a critical way. But after a long period, the intensity of interaction between the lecturer and students were wide opened. They discussed the individual tasks from their essay.

These essays were performed from their tasks. The essay content mainly talked about the phenomena occurred in the management of communication. The essay should be in two pages long by inserting the analysis of psychological theories of communication. Before discussing at class, it must be published in the personal blog, and Kompasiana internet sites account first. The writer serve as a moderator who controls the student's discussion at class. The moderator also helped to open critical perspective students to dare to argue in front of their friends. There were 40 essays for each class in the range of 7 meetings. Thus, the total essays on the blog were 120 written essays. One of the goals of the interactive learning method based on ICT was to increase the confident and critical perspective of the students. The essay characteristic must be critical, original, real-time, critical point of view, and cannot be a copycat from another blog essay. The combination of materials and interactive learning method based on ICT using internet technology have increased student critically on social awareness about the actual phenomenon in society. 


\section{CLOSURE}

\section{Conclusion}

The research that conducted in three classes of communication management course has successfully improved students' critical power. Students experience rapid development in pouring their critical ideas at class. Merging this learning model using technology in the classroom helps students become more courageous to pour their critical ideas. Active students can muffle the actualization ego in expressing their thinking. They begin to appreciate the thoughts of other students and become listeners. Passive students began to dare to speak although not too long and systematic in deciphering a case. Students who are smart but quiet more expressive express the contents of the head without hesitation mocked for being smart.

\section{Recomendation}

The conventional lecturing method is not the best and appropriate way for recent classes nowadays. Based on my research in three classes, some lacks found in the conventional lecturing method. Most of the students were not confident enough to express their opinion liberally. They prefer to listen rather than express their argument. After all, the lecturers get more score from the results of written assignments, the middle examination test, and final examination test only. The classroom action research using interactive learning method based on ICT should be a key facilitator in fostering students' critical power. However, this interactive learning method based on ICT method will not work effectively if the lecturer is less communicative. Brown (2007) said that the role of the teacher is that of facilitator and guide. Some lecturers still feel uncomfortable when getting students to be critical. They (lecturers) feel not ready to refute or argue again arguments of students who try to think out of the box. In fact, a critical attitude is part of academic freedom for academics. The use of interactive learning method based on ICT method should be one of the efforts to develop students' critical reasoning in a better direction to have the quality of learning. In addition, the use of instructional innovations using ICT-based interactive methods should be continuously improved to create enjoyable learning for students

\section{REFERENCES}

Brown, H.D. (2007) Teaching By Principles: An Interactive Approach to Language Pedagogy. 3rd edition. New Jersey, Prentice Hall Regents.

Cornu, B. (2011) Digital Natives: How Do They Learn? How To Teach Them? [Online]. 2011. Available from: http://unesdoc.unesco.org/images/0021/0021 66/216681e.pdf.

Degeng, I.N.S. (2004) Strategi Pembelajaran Mengorganisasi Isi dengan Model Elaborasi. Malang, IKIP dan IPTDI.

Gichuru, L.M. \& Mbayi, G.K. (2016) Digitization of Teaching and Learning Using the Interactive Whiteboard as an Instructional Tool: A Case Study of Hope Academy Rwanda. International Journal of Social Science and Humanities. [Online] 5 (6), 144-148. Available from: http://www.wrpjournals.com/sites/default/fil es/issues-pdf/1618.pdf.

Iriantara, Y. (2014) Komunikasi Pembelajaran: Interaksi Komunikatif dan Edukatif Di Dalam Kelas. Bandung, Simbiosa Rekatama Media.

Lee Swanson, H. \& Sachse-Lee, C. (2000) A Meta-Analysis of Single-Subject-Design Intervention Research for Students with LD. Journal of Learning Disabilities. [Online] 33 (2), 114-136. Available from: doi:10.1177/002221940003300201.

Sajjad, S. (2010) Effective Teaching Methods at Higher Education Level. Pakistan Journal of Special Education. 11, 29-43.

Seemiller, C. \& Grace, M. (2016) Generation Z Goes To College. San Francisco, John Wiley $\&$ Sons, Inc.

Slameto (2014) Developing Critical Thinking Skills through School Teacher Training 'Training and Development Personnel' Model and Their Determinants of Success. International Journal of Information and Education Technology. [Online] 4 (2), 161166. Available from: doi:10.7763/IJIET.2014.V4.390.

Supratman, L.P. (2015) A Case Study of Classroom Seating Arrangement to Promote Students Communication Interactivity in 
Telkom University. International Journal of Humanities, Arts and Social Sciences. 1 (3), 130-133.

World Bank (2014) World Bank and Education in Indonesia. [Online]. 2014. Available from: http://www.worldbank.org/en/country/indon esia/brief/world-bank-and-education-inindonesia [Accessed: 7 February 2018]. 